Weed Community in a Conventionally-Grown Olive Orchard Vs. Weed Community in Consociation with Pyrethrum (Tanacetum cinerariifolium (Trevir.) Sch. Bip.)

Usporedba korovne zajednice maslinika s konvencionalnim uzgojem $\mathrm{u}$ odnosu na maslinik u konsocijaciji $\mathrm{s}$ buhačem (Tanacetum cinerariifolium (Trevir.) Sch. Bip.)

Štefanić, E., Kovačević, V., Jakovljević, L., Kosić, U., Zima, D., Turalija, A.

Poljoprivreda/Agriculture

ISSN: 1848-8080 (Online)

ISSN: 1330-7142 (Print)

https://doi.org/10.18047/poljo.27.1.4

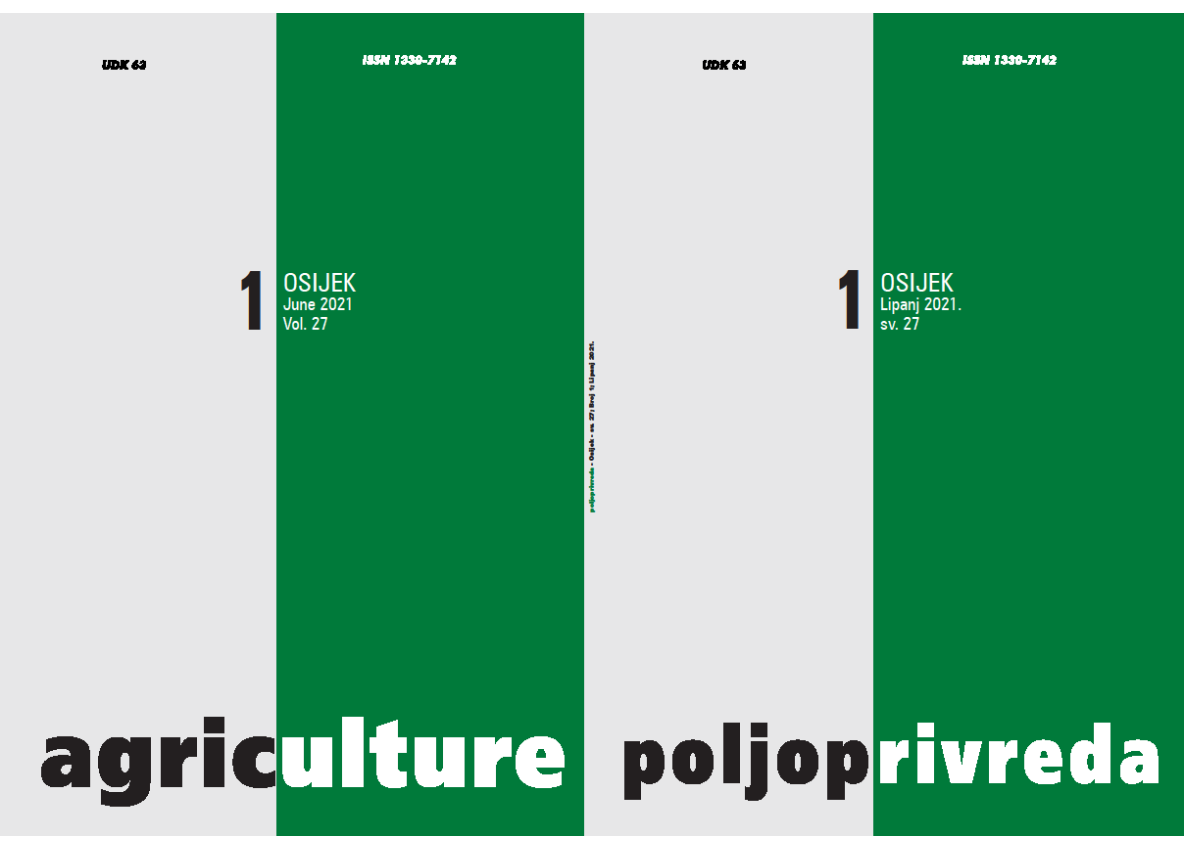

Fakultet agrobiotehničkih znanosti Osijek, Poljoprivredni institut Osijek

Faculty of Agrobiotechnical Sciences Osijek, Agricultural Institute Osijek 


\title{
WEED COMMUNITY IN A CONVENTIONALLY-GROWN OLIVE ORCHARD VS. WEED COMIMUNITY IN CONSOCIATION WITH PYRETHRUM (Tanacetum cinerariifolium (TREVIR.) SCH. BIP.)
}

Štefanić, E., (1) Kovačević, V., (2) Jakovljević, L., ${ }^{(2)}$ Kosić, U., ${ }^{(2)}$ Zima, D., ${ }^{(3)}$ Turalija, A. ${ }^{(1)}$

Preliminary communication Prethodno priopćenje

\begin{abstract}
SUMMARY
On the experimental plots of the Institute of Agriculture and Tourism in Poreč, weed communities were analyzed in a conventionally-grown olive orchard and in consociation with pyrethrum. Phytocenological surveys were conducted in March, June, and September using the Braun-Blanquet Cover Abundance Scale. Altogether, 54 species of vascular plants were recognized in both orchards. However, in a conventionally-grown olive orchard, 27 were identified, whereas 42 weed species were identified in consociation with pyrethrum. Only 15 weeds were common to both orchards. Between both olive orchards, significant differences existed regarding the floristic and community diversity metrics. In consociation with pyrethrum as a cover crop, olive orchard had a more stable weed community during the season, while two weed species, Mercurialis annuua $L$. and Medicago arabica (L.) Huds., dominated in a conventionally-grown orchard in the fall. The weed communities in both orchards significantly differ considering the appearance season (spring, summer, and fall). An autumnal weed community in a conventionally-grown olive orchard was more diverse, more abundant, and with a more distinct floristic composition than a weed community in the spring and summer periods. However, an olive-orchard weed community in consociation with pyrethrum also differed regarding the season, but a Canonical Correspondence Analysis (CCA) demonstrated a clear separation of a more diverse estival weed community than the one observed in the spring and summer.
\end{abstract}

Keywords: weed community, diversity, olive orchard, consociation, pyrethrum

\section{INTRODUCTION}

Olive cropping in Istria has a long tradition that dates back to the antique times and plays an important role in socioeconomic life of the region (Strikić at al., 2012). A traditional olive production, still implemented on the small-sized family farms, is based on the low tree densities (about 100 trees/ $/ \mathrm{ha}^{-1}$ ) and on a weed control that applies soil tillage. Nowadays, olive cropping in the investigated region is an important and profit-increasing activity, and the area under olive orchards is expanding to meet the growing olive-oil demand. To maximize the profit in a short-run, an intensive production manage- ment is recommended, whereby a crop-weed competition should be reduced while using intensive tillage (Carpio et al., 2020). However, this practice causes soil degradation and water scarcity, as well as a decline in the agroecosystem's plant diversity (Gómez et al., 2009). Although the advent of residual herbicides to

(1) Prof. Dr. Edita Štefanić (estefanic@fazos.hr), Alka Turalija, Ph. D. Josip Juraj Strossmayer University of Osijek, Faculty of Agrobiotechnical Sciences, V. Preloga 1, 31000 Osijek, Croatia, (2) Vesna Kovačević, Ph. D., Lea Jakovljević - student, Urška Kosić, Ph. D. - Polytechnic of Rijeka, Agricultural Department in Poreč, C. Huguesa 6, 52441 Poreč, Croatia, (3) Dinko Zima, Ph. D. - Polytechnic of Požega, Vukovarska 17, 34000 Požega, Croatia 
control the weeds has been tested as an alternative to the conventional tillage (Gómez et al., 1999), herbicide application caused serious problems regarding biodiversity, soil, and water quality (Simoes et al., 2014). In olive orchards, intercropping (consociation) was recognized as a simple and feasible solution regarding the suppression of the aforementioned problems (Soriano et al., 2016.).

The Dalmatian pyrethrum (Tanacetum cinerariifolium (Trevir.) Sch. Bip.) is a perennial herbaceous plant from the Asteraceae family, well-known because of its insecticidal activity and an ability to control or repel numerous insects' taxa with a little or with no adverse environmental impact (Casida and Quistad, 1995). The usage a pyrethrum as a cover crop in an olive orchard has been a long tradition along the Adriatic coast, yet with a scarce scientific information about the advantages or disadvantages of their consociation (Dudaš et al., 2014.).

Since the research effort has mostly been focused on the managemental techniques, it is still a necessity to obtain a deeper insight in preserving biodiversity, particularly during the process of alteration from a conventional into an integrative or ecological production. Therefore, this research's objective is to compare the biodiversity and seasonal dynamics of weed communities in a conventionally-grown olive orchard with the one in consociation with pyrethrum.

\section{MATERIAL AND METHODS}

On the experimental plots of the Institute of Agriculture and Tourism in Poreč $\left(45.2214{ }^{0} \mathrm{~N} 13.6026\right.$ $\left.{ }^{0} \mathrm{E}\right)$, the field surveys were conducted during the 2014 vegetation season in two olive orchards (Olea europaea L.). The climate in this area is typically as Mediterranean one, with July being the warmest month, measuring $30^{\circ} \mathrm{C}$ as an average temperature and having a very low humidity. January is the coldest month, with an average temperature measuring $5^{\circ} \mathrm{C}$. Annually, there are more than 3,850 sunshine hours, providing more than 10 sunshine hours on summer days. The average annual precipitation amounts to approximately 920 $\mathrm{mm}$, uniformly distributed throughout the year. These climatic conditions are favorable for a long season of a high potential olive growth, with a budbreak in February and a vegetative growth continuing well into November.

A conventionally-grown olive orchard was planted during 1990, while the other one was planted in 2013 in consociation with pyrethrum (Tanacetum cinerariifolim (Trevir.) Sch. Bip.) along tree rows to protect the orchard against insect pathogens (Krapac and Godena, 2014). Planting density in both orchards amounted to 277 olive trees per ha, arranged in the row lengths and intermediate distances of $6 \times 6 \mathrm{~m}$. N-P-K fertilizers and pesticides were applied following the recommended rates for the area (Bjeliš, 2009). Soil surface management between the rows in both orchards were as follows: winter soil cultivation $(20 \mathrm{~cm}$ depth), spring cultivation $(10-12 \mathrm{~cm}$ depth) and five shallow cultivations $(5-10 \mathrm{~cm}$ depth) during the summer months. Weed control inside the orchard rows were as follows: glyphosate ( $5 \mathrm{l} / \mathrm{ha}$ ) was applied prior to the vegetation start in the conventionally-grown olive orchards, but the weeds were controlled manually in an orchard in consociation with pyrethrum.

The weed communities' vegetation records in both olive orchards were obtained in March, June, and September using the 5-degree Braun-Blanquet Cover Abundance Scale (Braun-Blanquet, 1964) and were subsequently transformed to the ordinal scale (Van Der Maarel, 1979). Five phytosociological relevés at a standard surface size amounting to $100 \mathrm{~m}^{2}$ were performed in each study period (spring, summer, and fall), numbering 30 relevés in total. The following literature was used for the sake of plant identification: Dubravec and Dubravec (2002), Dubravec and Šegulja (2005), and Pericin (2001). Their nomenclatural treatment was adjusted according to a checklist of the Flora Croatica Database (https://hirc.botanic.hr/fcd/).

Primarily, all the raw data were deployed for the sake of community evaluation, including a construction of the Venn diagram to determine the number of species distributed at, or being exclusive to, each type of olive orchard management throughout the season (spring, summer, and fall). Subsequently, mean comparisons of conventionally-grown olive orchards and the olive orchards in consociation with pyrethrum were calculated for each index (Shannon's $H$ index and evenness $(E)$ ) averaged at the site scale while using a sample t test $\left(\mathrm{H}_{0}=\right.$ conventional $=$ consociation). Normality tests for indices were conducted by the sample KolmogorovSmirnov test. The abovementioned statistical testing was performed by the IBM's SPSS Statistics v. 22 software. A rank abundance curve (Whittaker, 1967) for each season (spring, summer, and fall) was developed by plotting the cumulative relative abundance values against the species rank in both orchards. A species composition variation during the season was examined in each orchard by a unimodal Canonical Correspondence Analysis (CCA) while applying the CANOCO 5 (Ter Braak and Smilauer, 2012). A statistical significance of the fitting CCA was examined using a global permutation test (Monte Carlo test) of the species data in 499 iterations. In the ordination diagrams, the species names were abbreviated using the EPPO codes (https://www.eppo. int/RESOURCES/eppo_databases/eppo_codes).

\section{RESULTS AND DISCUSSION}

In total, 54 species of vascular plants (belonging to 29 families) were detected during the survey in both olive orchards being a typical flora of the region (Štefanić et al., 2018). Asteraceae (seven taxa), Euphorbiaceae (six taxa), Poaceae (five taxa), Cichoriaceae (four taxa) and 
Fabaceae (four taxa) families were the most representative ones in terms of species richness and were already confirmed by a previous research (Štefanić et al., 2019). However, there were 27 weed species identified in a conventionally-grown olive orchard, while 42 weed species were identified in an olive orchard cultivated in consociation with pyrethrum. From a total of 54 taxa detected during the study period, there were only 15 common to both orchards. Also, a low number of common species (five in spring, four in summer, and seven in the fall) was observed throughout the growing season (Fig. 1).
A means comparison by the ANOVA indicated the existence of significant differences between a conventionally-grown olive orchard and an orchard cultivated in consociation with pyrethrum for all the indices measured (Table 1). However, in a conventional type of olive-orchard cultivation, the average species richness and average species per relevé were substantially lower during the spring and summer period than in the fall, while there were no significant differences in species richness throughout the season in an olive orchard cultivated in consociation with pyrethrum.

Table 1. Summary vegetation variables (floristic data and community diversity metrics)

Tablica 1. Prikaz istraživanih varijabla (floristički podatci i podatci o raznolikosti korovne zajednice)

\begin{tabular}{|c|c|c|c|c|c|c|c|c|c|c|}
\hline & \multicolumn{4}{|c|}{$\begin{array}{c}\text { Conventionally grown orchard } \\
\text { Maslinik s konvencionalnim uzgojem }\end{array}$} & \multicolumn{4}{|c|}{$\begin{array}{l}\text { Orchard in consociation with pyrethrum } \\
\text { Maslinik u konsocijaciji s buhačem }\end{array}$} & \multirow[b]{2}{*}{ t-stat } & \multirow[b]{2}{*}{$\mathrm{P}^{*}$} \\
\hline & 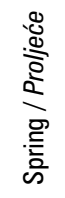 & 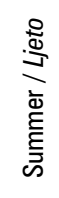 & 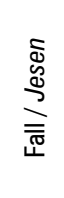 & 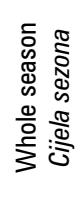 & 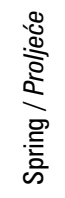 & 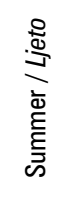 & 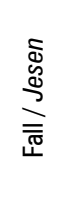 & 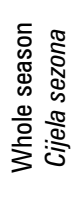 & & \\
\hline \multicolumn{11}{|c|}{ Floristic summary data / Floristički podatci } \\
\hline Total species richness & 9 & 6 & 23 & 27 & 16 & 24 & 19 & 42 & 4.78 & .005 \\
\hline Species average per relevés & 6 & 4.2 & 15.4 & 8.5 & 9.4 & 8.6 & 9.2 & 8.73 & 5.63 & .002 \\
\hline Plant family number & 7 & 6 & 19 & 21 & 11 & 16 & 12 & 22 & 5.75 & .002 \\
\hline \multicolumn{11}{|c|}{ Community diversity metrics ${ }^{* *}$ / Podatci o raznolikosti korovne zajednice } \\
\hline Shannon's diversity index $\left(\mathrm{H}^{\prime}\right)$ & 0.95 & 0.78 & 1.36 & 1.03 & 1.20 & 1.38 & 1.28 & 1.87 & 11.72 & .000 \\
\hline Evenness (E) & 0.43 & 0.44 & 0.43 & 0.31 & 0.43 & 0.43 & 0.40 & 0.50 & 76.49 & .000 \\
\hline
\end{tabular}

${ }^{*}$ significant difference at the 0.05 level; ${ }^{* *}$ significant difference at the 0.01 level

${ }^{* *}$ Shannon-Wiener Index of Diversity $\left(H^{\prime}\right)=P\left[p_{i} \mid n\left(p_{i}\right)\right]($ Whittaker, 1975$) ; p_{i}$ is a relative proportion value of each species; Evenness $=H^{\prime} /$ In $($ richness $)(G u r e v i t c h$ et al., 2002)

Both indices (evenness and Shannon's diversity index) ranked the olive orchard in consociation with pyrethrum higher than a conventionally-grown orchard. It is also observed that the values and diversity indices' variation in a conventionally-grown olive orchard existed during the growing season as well, having significantly lower values in the spring and summer when compared to a diverse fall period. Its decrease in certain seasonal periods is generally indicative of a change in the dominance structure (Magurran, 1992).

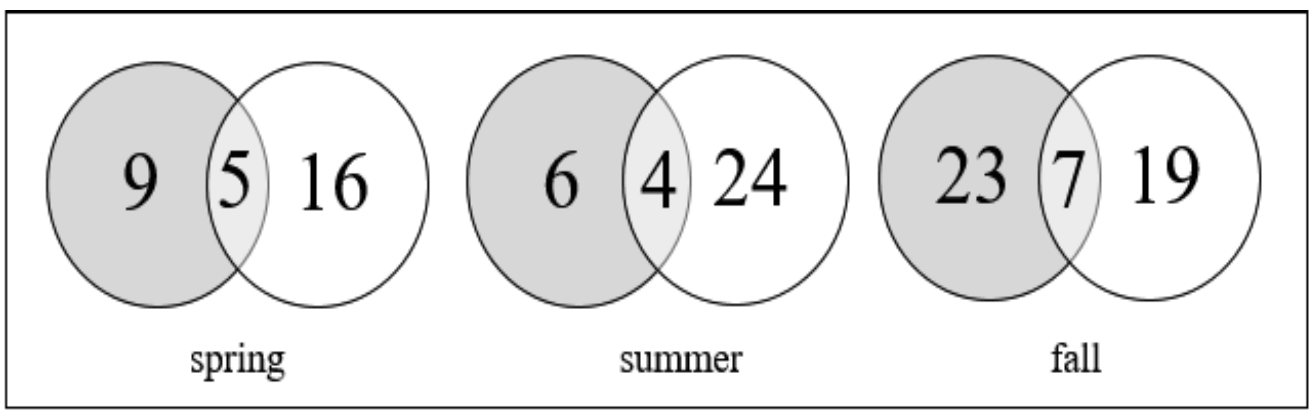

Figure 1. Wenn diagram with the number of weed community species detected in a conventionally-grown olive orchard (grey) and in an olive orchard cultivated in consociation with pyrethrum (no fill) in the spring, summer and fall

Slika 1. Wennov dijagram s brojem vrsta u korovnoj zajednici maslinika s konvencionalnim uzgojem (sivo) i maslinika u konsocijaciji s buhačem (bijelo) tijekom proljetnoga, ljetnog i jesenskog razdoblja 
The structure and diversity of weed communities presented by the dominance-diversity curves reflect their species structure and, hence, allows for a better interpretation of the abundance ratio between the species, compared to the individual diversity indices (Maguran, 1992). It is visible from Figure 2 that all curves were similar across the seasons (spring, sum- mer, and fall) in an orchard cultivated with consociation with pyrethrum. However, in a conventionally-grown olive orchard, two weed species (Mercurialis annua L. and Medicago arabica (L.) Huds.) dominated in the fall, which was depicted by a slope on the dominance-diversity curve.
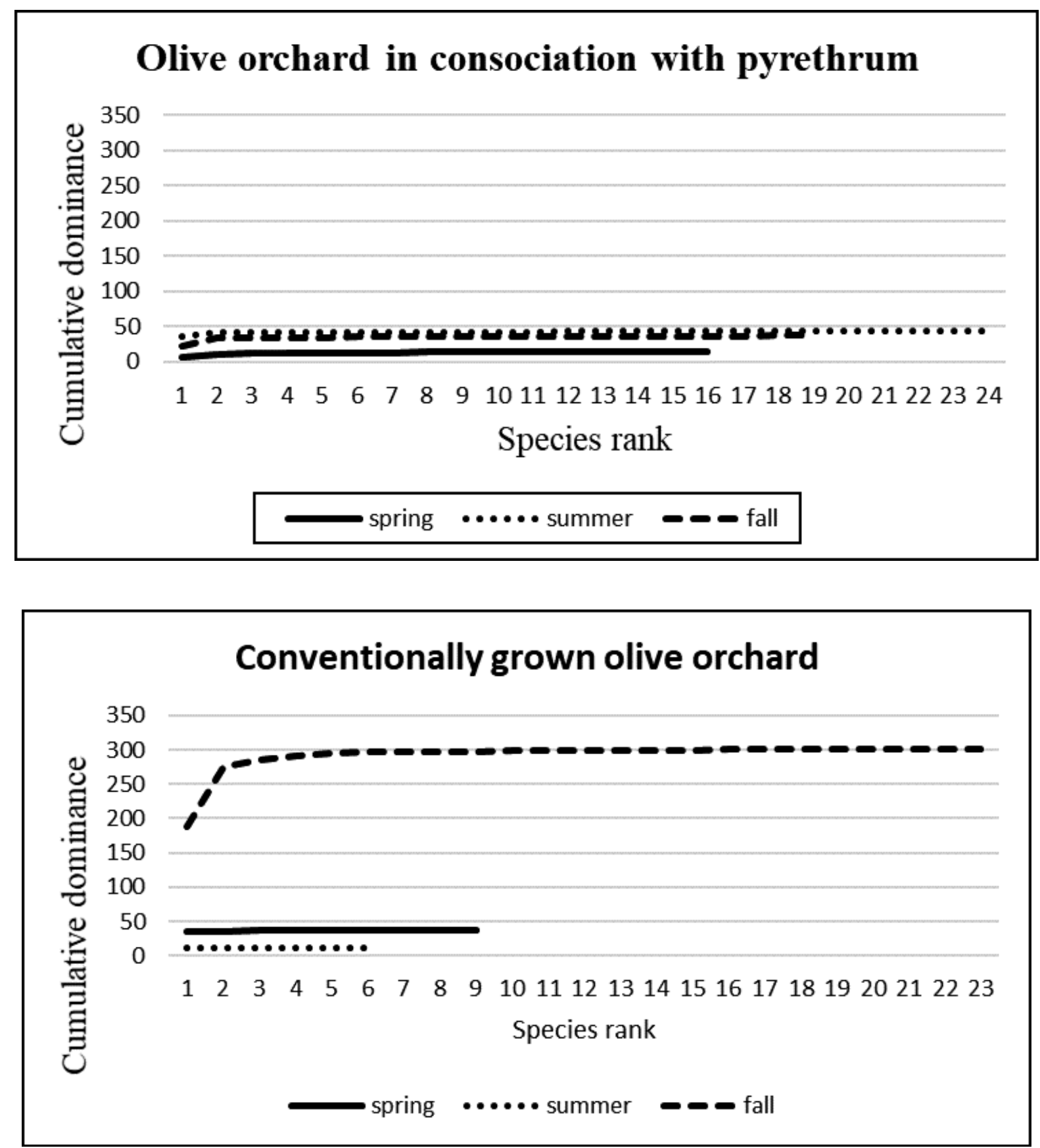

Figure 2. Dominance-diversity curve for each olive orchard as a measure of cumulative dominance of species in the spring, summer, and fall

Slika 2. Krivulje dominacije-raznolikosti za svaki od istraživanih maslinika kao mjera kumulativne dominacije vrsta tijekom proljetnoga, ljetnog i jesenskog razdoblja 
Figure 3 depicts the ordination diagram (CCA) with a spatial distribution of plant species in relation to the appearance season. In a conventionally-grown olive orchard $(A)$, the first axis explains $94.45 \%$ of species composition variability (Table 2) and divides the weed communities that were developed during the fall period from those developed in the vernal and estival months. Significant differences in floristic composition between those periods can be explained by a lower abundance and weed cover values that have been developed during the first part of the vegetation season, when the herbicides and an intensive soil management affected the weed community (Carpio et al., 2020). As a cover crop in an olive orchard, pyrethrum (B) indicated a better biodiversity conservation (Simoes et al., 2014). However, this practice also distinguishes a weed community throughout the season, particularly an estival weed community (Axis 1 explained $57.86 \%$ of the species composition variability, Table 2). Considering Axis 2 , the vernal weed communities in both orchards (Fig. 3 , A and B, Table 2) were compositionally different from the estival and autumnal ones, although a glyphosate application decreases richness in a conventionallygrown olive orchard.
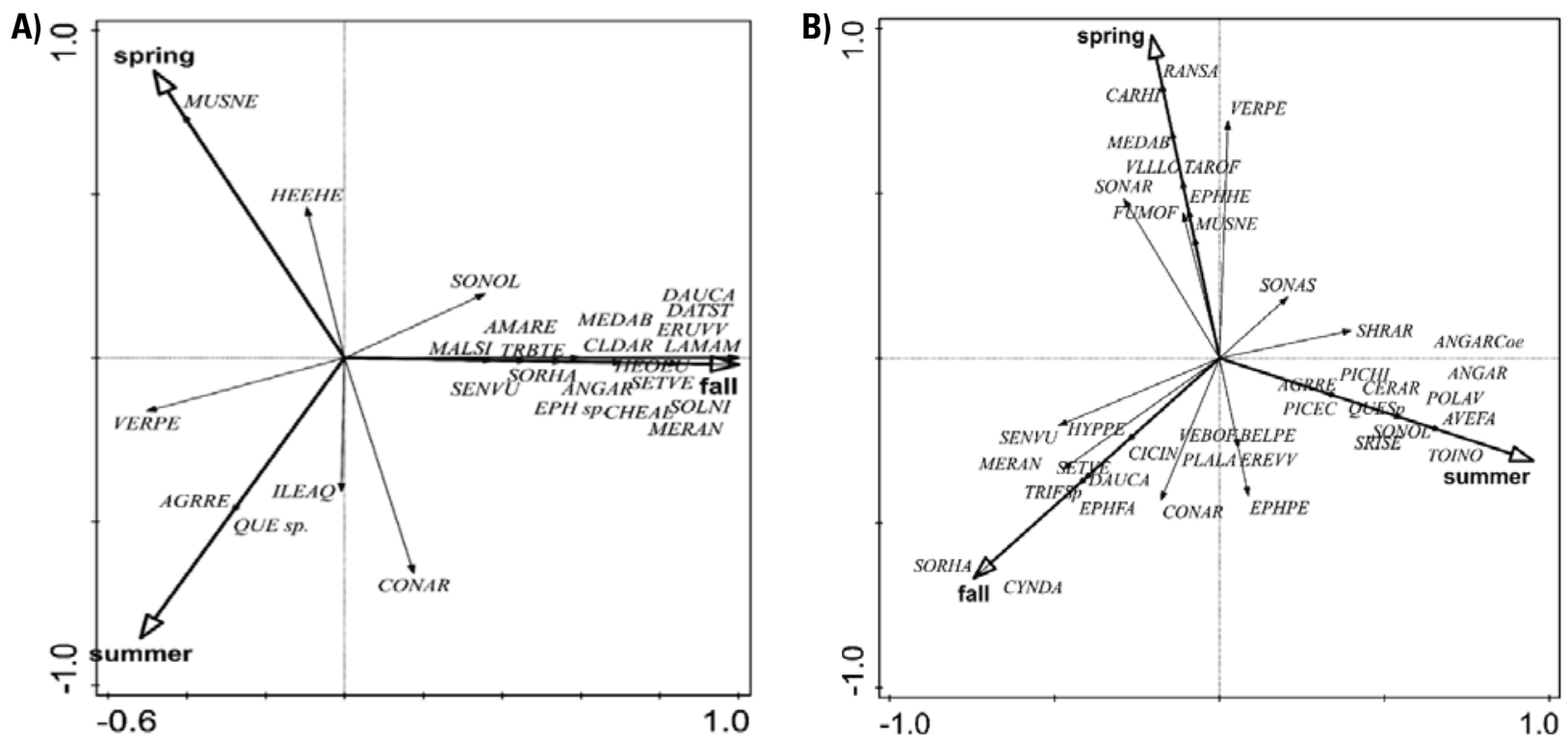

Figure 3. Ordination diagram of the Canonical Correspondence Analysis (CCA), depicting a correlation between a weed cover and a season (spring, summer, fall) for a conventionally-grown olive orchard $(A)$ and an olive orchard cultivated in consociation with pyrethrum (B)

Slika 3. Ordinacijski dijagram kanoničke korelacijske analize (CCA) s prikazom korelacije između pokrovnih vrijednosti korova tijekom istraživanja (proljeće, ljeto, jesen); $A$ - prikaz za maslinik u konvencionalnome uzgoju, B - prikaz za maslinik u konsocijaciji s buhačem

Table 2. A summary of the CCA analysis pertaining to the relationship between a weed cover and a season (spring, summer, and fall) for a conventionally-grown olive orchard (A) and an olive orchard cultivated in consociation with pyrethrum (B). Only the first two axes are depicted

Tablica 2. Sažetak CCA analize odnosa između pokrovnih vrijednosti korova s obzirom na sezonu uzimanja uzoraka (proljeće, ljeto, jesen) za maslinik s konvencionalnim uzgojem i maslinik u konsocijaciji s buhačem. Prikazane su samo prve dvije osi

\begin{tabular}{|l|c|c|c|c|}
\hline \multirow{2}{*}{} & \multicolumn{2}{|c|}{$\begin{array}{c}\text { Conventionally grown olive orchard } \\
\text { Maslinik s konvencionalnim uzgojem }\end{array}$} & \multicolumn{2}{c|}{$\begin{array}{c}\text { Olive orchard in consociation with pyrethrum } \\
\text { Maslinik u konsocijaciji s buhačem }\end{array}$} \\
\cline { 2 - 5 } & Axis 1 & Axis 2 & Axis 1 & Axis 2 \\
\hline Eigenvalues & 0.7436 & 0.0437 & 0.1645 & 0.1198 \\
\hline Explained variation (cumulative) & 74.36 & 78.73 & 16.45 & 28.42 \\
\hline Pseudo-canonical correlation & 0.9984 & 0.5596 & 0.6777 & 0.5929 \\
\hline Explained fitted variation & 94.45 & 100.00 & 57.86 & 100.00 \\
\hline
\end{tabular}

\section{CONCLUSION}

During this study, a clear effect of pyrethrum (Tanacetum cinerariifolium (Trevir.) Sch. Bip.) as a cover crop on a plant species diversity was observed in an olive orchard. A biodiversity conservation was promoted by a richer and more stable plant community, if compared to a conventional and intensive olive cropping, where a decline in plant diversity may be detrimental to the overall eco- 
system equilibrium. Contrary to our hypotheses, the weed communities in the investigated olive orchard differ in a floristic composition, richness, weed cover and diversity.

\section{REFERENCES}

1. Bjeliš, M. (2009). Zaštita masline u ekološkoj proizvodnji. Solin, II prošireno izdanje.

2. Braun-Blanquet, J. (1964). Pflanzensoziologie. Grundzüge der vegetationskunde. Wien, New York: Springer Verlag

3. Carpio, A. J., Lora, A., Martin-Consuegra, E., SanchezCuesta, R., Tortosa, F. S., \& Castro, J. (2020). The influence of the soil management systems on aboveground and seed bank weed communities in olive orchards. Weed biology and Management, 20(1),12-23. https://doi.org/10.1111/wbm.12195

4. Casida, J. E., \& Quistad, G. B. (1995). Pyrethrum flowers: Production, Chemistry, Toxicology and Uses. Oxford University Press, New York

5. Dubravec, K. D., \& Dubravec, I. (2002). Biljne vrste livada i pašnjaka. Školska knjiga, Zagreb.

6. Dubravec, K. D., \& Šegulja, N. (2005). Korovi obradivih površina Istre. Veleučilište u Rijeci, Rijeka-Poreč.

7. Dudaš, S., Ban, D., Krapac, M., Ferenčić, D., \& Babić, H. (2014). Evaluacija buhača iz uzgoja u konsocijaciji s maslinom. Zbornik radova 49. hrvatskog i 9. međunarodnog simpozija agronoma, 16.-21.02., Dubrovnik, Hrvatska, 296-300.

8. Gómez, J. A., Giráldez, J. V., Pastor, M., \& Fereres, E. (1999). Effects of tillage method on soil physical properties, infiltration and yield in an olive orchard. Soil and Tillage Research, 52(3-4), 167-175. https://doi.org/10.1016/S0167-1987(99)00078-1

9. Gómez, J. A., Sobrinho, T. A., Giráldez, J. V., \& Fereres, E. (2009). Soil management effects on runoff, erosion and soil properties in an olive grove of Southern Spain. Soil and Tillage Research, 102(1), 5-13. https://doi.org/10.1016/j.still.2008.05.005

10. Gurevitch, J., Scheiner, S. M., Fox, \& G. A. (2002). The Ecology of Plants. Sinauer Associates, Inc., Sunderland, MA.

11. Krapac, M., \& Godena, S. (2014). Maslina i buhač. Agronomsko i ekonomsko vrednovanje konsocijacije maslina-dalmatinski buhač. http://www.iptpo.hr/images/pdf/maslina\%20i\%20buhac_brosura.pdf
12. Maguran, A. E. (1992). Ecological Diversity and its Measurement. London, Croom Helm

13. Pericin C. (2001). Fiori e piante dell'Istria distribuite per ambiente. Unione Italiana-Fiume, Universita Popolare di Trieste, Rovigno-Trieste.

14. Simoes, M., Belo, A. F., Pinto-Cruz, C., Pinheiro, \& A. C. (2014). Natural vegetation management to conserve biodiversity and soil water in olive orchards. Spanish Journal of Agricultural Research, 12(3), 633-643. http://doi.org/10.5424/sjar/2014123-5255

15. Soriano, M. A., Cabezas, J. M., Ramos, A. L., \& Gomez, J. A. (2016). Characterization of cover crops for use in olive groves and vineyards in certified systems under Mediterranean conditions. In: AgroEnviron2016. $10^{\text {th }}$ International Symposium on Agriculture and the Environment, Purdue University, West Lafayette, IN (USA), May 23-27. http://docs.lib.purdue.edu/agroenviron/2016/

16. Strikić, F., Gugić, J., \& Klepo, T. (2012). Stanje hrvatskog maslinarstva. Glasilo biljne zaštite, 12(4), 271-276.

17. Štefanić, E., Kovačević, V., \& Antunović, S. (2018). Decline of arable flora diversity in Istria (from the year 2005 to the year 2017). Zbornik Veleučilišta u Rijeci, 6(1), 385-398. http://doi.org/10.31784/zvr.6.1.25

18. Štefanić, E., Kovačević, V., Antunović, S., JapundžićPalenkić, B., Zima, D., Turalija, A., \& Nestorović, N. (2019). Floristic biodiversity of weed communities in arable lands of Istria Peninsula (from 2005 to 2017). Ecologia (Bratislava), 38(2), 166-177. http://doi.org/10.2478/eko-2019-0013

19. Ter Braak, C. J. F., \& Šmilauer, P. (2012). CANOCO 5. Canoco reference manual and user's guide. Biometris, Wageningen and České Budějovice, pp.496.BM Corp. Released 2013. IBM SPSS Statistics for Windows, Version 22.0. Armonk, NY: IBM Corp.

20. Van der Maarel, E. (1979). Transformation of coverabundance values in phyto-sociology and its effect on community similarity. Vegetatio, 39(2), 97-114. https://www.jstor.org/stable/20145666

21. Whittaker, R. H. (1967). Gradient analysis of vegetation. Biological Reviews 42, 207-264.

22. Whittaker, R. H. (1975). Communities and Ecosystems, second ed. Macmillan Publishing Co., Inc., NY. 


\title{
USPOREDBA KOROVNE ZAJEDNICE MASLINIKA S KONVENCIONALNIM UZGOJEM U ODNOSU NA MASLINIK U KONSOCIJACIJI S BUHAČEM (Tanacetum cinerariifolium (TREVIR.) SCH. BIP.)
}

\begin{abstract}
SAŽETAK
U radu su analizirane korovne zajednice maslinika s konvencionalnim uzgojem i u konsocijaciji s buhačem zasađenim na eksperimentalnim površinama Instituta za poljoprivredu i turizam u Poreču. Fitocenološka istraživanja provedena su tijekom ožujka, lipnja i rujna Braun-Blanquetovom metodom kombinirane procjene brojnosti $i$ pokrovnosti. Sveukupno su u oba maslinika utvrđene 54 svojte vaskularne flore. Međutim, u masliniku s konvencionalnim uzgojem determinirano je 27, a u konsocijaciji s buhačem determinirane su 42 korovne vrste. Samo je 15 korovnih vrsta bilo zajedničko za oba maslinika. Signifikantne razlike između maslinika utvrđene su kako za florističku, tako i za metriku na razini korovne zajednice. U konsocijaciji s buhačem prisutna je mnogo stabilnija korovna zajednica tijekom cijele vegetacijske sezone, dok u masliniku s konvencionalnim uzgojem u jesenskome razdoblju dominiraju korovne vrste Mercurialis annua L. i Medicago arabica (L.) Huds. Korovne zajednice u oba maslinika značajno se razlikuju i unutar vegetacijske sezone (proljeće, ljeto, jesen). Korovna zajednica u jesenskome periodu maslinika s konvencionalnim uzgojem bila je mnogo bujnija i raznolikoga florističkog sastava od one u proljeće i ljeto. Korovna zajednica maslinika u konsocijaciji s buhačem također se razlikuje ovisno o vegetacijskoj sezoni. No, CCA analiza pokazala je jasno razdvajanje raznolikije korovne zajednice u ljetnome razdoblju u odnosu na njezin floristički sastav u proljeće i ujesen.
\end{abstract}

Ključne riječi: korovna zajednica, bioraznolikost, maslinik, konsocijacija, dalmatinski buhač

(Received on January 26, 2021; accepted on April 6, 2021 - Primljeno 26. siječnja 2021.; prihvaćeno 6. travnja 2021.) 